\title{
THE EFFECTIVENESS OF STUDENT TEAMS ACHIEVEMENT DIVISION (STAD) IN TEACHING READING COMPREHENSION OF THE FIRST SEMESTER STUDENTS OF ENGLISH LANGUAGE EDUCATION STUDY PROGRAM
}

\author{
Yusniarsi Primasari \\ yusniarsi2015@gmail.com \\ Universitas Islam Balitar \\ Blitar
}

\begin{abstract}
Strategy plays the important role to make students understand reading materials. Teachers should be able to choose right teaching strategy in order to make the students interested more in learning beacause they enjoy learning and reading the given material. This study was conducted to find out whether the use of STAD in teaching of reading comprehension is effective to improve the student reading comprehension achievement. The design of the study was experimental reasearch. The study was conducted in Islamic University of Balitar. the researcher takes one class of the first semester students of english language education study program in the islamic university of balitar blitar in the academic year 2016/2017. and in analyzing the data, the researcher used the statistical procedures namely dependent T-test. The finding of this study is the score that students got after treatment increased. It means that the hypothesis alternative is accepted and the null hypothesis is rejected. By those facts, Ho hypothesis is rejected and $\mathrm{H} 1$ hypothesis is accepted. Thus, it can be concluded that using STAD method in teaching reading comprehension proved to be effective in increasing teh students' reading comprehension achievement.
\end{abstract}

Keywords: Student Teams Achievement Division (STAD), Reading Comprehension,

\section{Abstrak}

Strategi memainkan peran penting untuk membuat siswa memahami bahan bacaan. Guru harus dapat memilih strategi pengajaran yang benar agar siswa lebih tertarik untuk belajar dan membaca materi yang diberikan. Penelitian ini dilakukan untuk mengetahui apakah penggunaan STAD dalam pengajaran pemahaman bacaan efektif untuk meningkatkan prestasi belajar membaca siswa. Rancangan penelitian ini adalah penelitian eksperimental. Penelitian dilakukan di Universitas Islam Balitar. Peneliti mengambil satu kelas mahasiswa semester 1 
program studi Pendidikan Bahasa Inggris di Universitas Islam Balitar Blitar pada tahun akademik 2016/2017. Dalam menganalisa data, peneliti menggunakan prosedur statistik yaitu dependent T-test. Temuan penelitian ini adalah skor yang didapat siswa setelah treatment meningkat. Artinya alternatif hipotesis diterima dan hipotesis nol ditolak. Dengan fakta tersebut, hipotesis Ho ditolak dan hipotesis H1 diterima. Dengan demikian dapat disimpulkan bahwa penggunaan metode STAD dalam pengajaran membaca dengan pemahaman terbukti efektif dalam meningkatkan prestasi belajar membaca siswa.

\section{Kata Kunci: Divisi Prestasi Regu Siswa, Membaca Pemahaman.}

In Indonesia, based on curriculum English is introduced starting from elementary school to university. Although English is taught since primary school, understanding English is not always easy for students. In studying English, students need to understand how to use language. To achieve this aim, teacher should apply his or her teaching directly towards the development of the students' competence in all languange skills.

In general, the skills involved in mastering English are reading, speaking, listening, and writing. Among them, reading is the most important factor that can support the process of mastering the other skills and improve knowledge. Reading is the base in learning English. Through reading, students can broaden their knowledge. Based on Grabe (2010:5), Citizens of modern societies must be good readers to be successful. Reading skill does not guarantee success for anyone, but success is much harder to come by without being a skilled reader.

In fact, reading is one of the supported English skills that the students should master if they want to acquire a good mastery of English. Moreover, reading is also has a very strategic position in the teaching and learning English in university.

Reading without comprehension is nothing. In doing so, the students who have good reading ability are going to be able to absorb the knowledge of English through the text. If they lack reading ability, they will fail to catch the information from the text and will almost likely be inefficient reader.

Students need to understand what it means to learn the skills to read English text for themselves, what the benefits are and how their efforts to achieve them so that they realize that what they learn is useful for their future. However, teachers who teach reading faced some problems in teaching reading. These problems include the lack of students' interest to learn English so the learning activities students' readings tend to be low. The students usually only read the text, and they didn't understand what they read. There are some reasons why reading felt difficult to be mastered by the students. First, the students are not interested in reading. Second, they have lack of vocabulary mastery and the last they have lack of imagination about contents of the text. 
In this research, the writer proposed that Student Teams Achievement Divisions (STAD) is the most suitable method for teching reading. Slavin (1995: 71) clarified that STAD is one of the simplest of all CL methods, and is a good model to begin with for teachers who are new to the cooperative approach. STAD is one of the CL methods which emphasizes on teamwork for achieving learning objectives. It also commits and is responsible among heterogenous group members in mastering the materials. The role of group is very important to facilitate their member to do actively and sharing knowledge through peer teaching by the members who own the high achievement. STAD method can be used as an alternative method for teaching reading at Islamic University of Balitar Blitar and it could make students more active, or students centered teaching learning process. The role of teacher is supporting all of the students for taking part in their group, so teaching and learning process will run effectively.

For the purpose of teaching rading comprehension, in this study, the reseacher uses Student Teams Achievement Divisions (STAD) as a strategy to improve the student reading comprehension achievement. The setting of this study is on the first semester students of English Language Education Study Program in the Islamic University of Balitar Blitar in the academic year 2016/2017.

\section{Method}

Research is a process of steps used to collect and analyze information to increase our understanding of a topic or issue. It is started with a question, collect some information, and then form an answer (Creswell, 2008: 3). This research design used in this research is an experimental research design. An experimental is scientific investigation in which the researcher manipulates or more independent variables, controls any other relevant variables and observes the effect of the manipulations on the dependent variables (Ari, et al, 2002: 276).

This research adopts a pre-experimental design for its design since there is no random assignment applied to the subject of the study. The pretest used to get the score before the treatment given. The treatment was given to the experiment group for specified time. After that, the teacher gave a post-test. The post-test was conducted to get the score after the treatment and then these average differences scores between the pre-test and post-test. The significance of difference average changes is determined by an appropriate statistical such as dependent T-test.

According to Creswell (2008:123), a variable is a characteristics or attribute of an individual or an organization that researcher can measure or observe and varies among individuals or organizations studied. There are two kinds of variables to be investigated. They are independent and dependent variables. In this study, the researcher takes one class of the first semester students of English Language Education Study Program in the Islamic University of Balitar Blitar in the academic 
year 2016/2017. The number of population is 32 students. The researcher used the

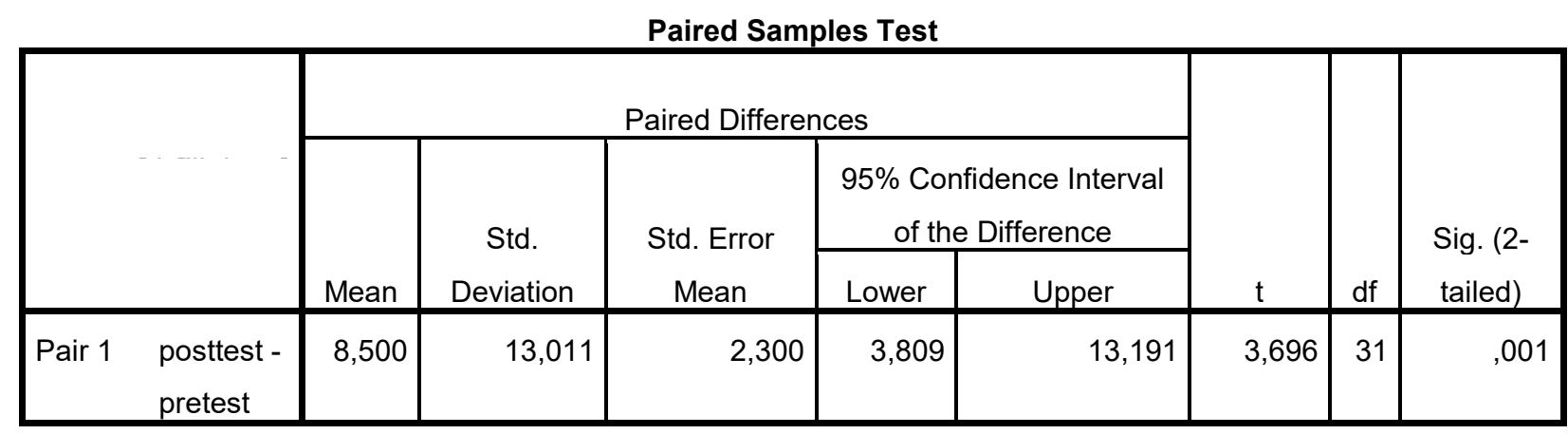

eight texts for preliminary test, treatment, and also post test.

\section{Result}

In analyzing the data, the researcher used quantitative approach. The researcher used the statistical procedures namely SPSS 18. In this study the researcher wants to know whether the students got better scores after taught using Student Teams Achievement Divisions (STAD) or not using Student Teams Achievement Divisions (STAD) strategy in reading comprehension.

\begin{tabular}{|c|c|c|c|c|c|}
\hline \multicolumn{1}{|c|}{ Descriptive Statistics } \\
\hline pretest & 32 & 24 & 88 & 58,00 & 16,438 \\
posttest & 32 & 40 & 84 & 66,50 & 13,744 \\
Valid N (listwise) & 32 & & & & \\
\hline
\end{tabular}

From the result above, the computation using SPSS 18 as follows:

a. Mean of differences (MD) between pretest and posttest is 8.5

b. The standard deviation of differences $\left(\mathrm{SD}_{\mathrm{D}}\right)$ between pretest and posttest is 13.011

c. The standard error from the mean of differences $\left(\mathrm{SE}_{\mathrm{MD}}\right)$ between pretest and posttest is 2.3

d. The result of observation (to) is 3.696

e. The degree of freedom is 31 
The obtained t-value is 3.696 while the required critical $t$-value is at $p>$ .05 level significance of two tailed test is $2.040(\mathrm{df}=31)$, and $\mathrm{p}>.01$ level significant of two tailed test is $2.744(\mathrm{df}=31)$. The result of observation more than t-table .01 level significance, so the students' score in posttest better than students' score in pretest.

The result of the data in this study showed that there was different result between score in pretest and post test. It can be seen at the table of students' score on pretest and post test. From the experiment conducted through Student Teams Achievement Divisions (STAD) strategy, the result obtained that from 32 students who performed pretest appreciates in value by 6 students passed the criteria of success and 26 students failed the criteria of success. Then, the result obtained that from 32 students who performed post test appreciates in value by 13 students passed the criteria of success and 19 students failed the criteria of success.

In teaching and learning reading comprehension used Student Teams Achievement Divisions (STAD) strategy, the researcher used literal and inferential comprehension to made specification of test. Based on the result, majority of the students answered questions in literal comprehension because the key answer had done on the texts, so it made the students easy to answer.

Analysis of SPSS 18 showed that the t-value is 3.696 and the significant value .01 . Thus, it can be concluded that pretest score in reading comprehension and post test score different significantly. And the hypothesis of the study is that the students taught by using Student Teams Achievement Divisions (STAD) strategy have better score in the reading comprehension.

After the researcher did this research, there is a difference score of the students who are after being taught reading comprehension with the Student Teams Achievement Divisions (STAD) strategy with the students' before being taught reading comprehension with Student Teams Achievement Divisions (STAD) strategy. After they were given a treatment by Student Teams Achievement Divisions (STAD) strategy, they have got better score in reading comprehension on their post test. So the research hypothesis is accepted, it is that the first semester students of English Language Education study program in the Islamic University of Balitar Blitar in the academic year 2016/2017 have better reading comprehension after being taught with Student Teams Achievement Divisions (STAD) strategy than before being taught with Student Teams Achievement Divisions (STAD) strategy. The null hypothesis is rejected, that the first semester students of English Language Education study program in the Islamic University of Balitar Blitar in the academic year 2016/2017 have not better reading comprehension after being taught with Student Teams Achievement Divisions (STAD) strategy than before being taught with Student Teams Achievement Divisions (STAD) strategy. 


\section{Discussion}

Based on that consideration and steps conducted by the reseacher, showed that the t-value is 3.696 and the significant value .01 . Thus, it can be concluded that pretest score in reading comprehension and post test score different significantly. And the hypothesis of the study is that the students taught by using Student Teams Achievement Divisions (STAD) strategy have better score in the reading comprehension.

STAD is more effective than Conventional method to teach reading. STAD emphasizes on the students' role in teaching and learning process, through a small group learning (four persons) with different background. Conventional method emphasizes on individual work in mastering the learning materials. Students are the object of learning, because they do the activity based on the teacher and teacher's instruction. It's different from STAD where students should manage their activity with their team-mates in their group. The teacher presents a lesson, and then students work in their teams to make sure all team members have mastered the lesson (Slavin, 1995: 5). A study conducted by Triya Novika Ningrum in 2012 came to conclusion that the students in experimental class have higher achievement after they were taught by STAD technique. The data proves that it was effective to use STAD technique in improving students' ability reading comprehension. Istirocha Murtanti Cahyani in 2013 also came to conclusion that the students which are taught using STAD have higher score than taught without STAD.

It is widely known that each student has different level of English skill. Tachers often think that the mastery of grammar, speaking and listening are much more important while students feel that reading comprehension are boring. In this condition, the use of STAD could help the students problem. Teaching reading comprehension using Student Teams Achievement Divisions (STAD) are more challenging, interesting and able to get alot of attention and full participation on the students.

\section{Conclusion and Suggestions}

\section{Conclusion}

Based on the research findings, the conclusion is that the Student Teams Achievement Divisions (STAD) is an effective method for teaching reading comprehension to university students to improve their reading skill achievement. Since the Student Teams Achievement Divisions (STAD) is done based on the right procedure, it is able to attract the students to be more active in teaching and learning process. When the students are active in the teaching and learning process, their achievement on reading comprehension can surely improved optimally. 


\section{Suggestion}

For Teacher, researcher has four suggestions. First, teacher should use STAD method for teaching reading to improve student reading competence. Second, teachers hould monitor the activity of the groups and their members. Third, Teacher should avoid the domination of certain members in group while they do the activity especially in completing the task. Fourth, Teacher may modified the procedure based on their class situation.

For Future Reseachers, researchers can use the result of this study as the starting point for further research in the same field with different text types and can also use it as a reference for other studies in different field.

\section{References}

Ary, D., Jacobs, C. L., Rezavieh, A. 2002. Introduction to Research in Education Sixth Edition. United States: Wadsworth Tomson Learning.

Brown, H. D. 2001. Teaching by Principles an Interactive Approach to language Pedagogy ( $\left.2^{\text {nd }} E D\right)$ ). San Francisco: San Francisco State University.

Byrnes. 1998. Strategies for Developing Reading Skills. (on line), (http://niaidroose.wordpress.com/ strategies - for - developing - reading skills/, downloaded on April 04 ${ }^{\text {th }}, 2014$ ).

Cahyani, I. M. 2013. The Effect of Student Teams Achievement Division (Stad) on Students' Reading Comprehension Ability.

http://www.fkipunisma.ac.id/wp-content/uploads/2013/08/Istirocha-

Murtanti-Cahyani_2013.pdf, accessed on April 09 ${ }^{\text {th }}, 2014$.

Creswell, John W. 2008. Educational Research (Planning, Conducting, and Evaluating Quantitative, and Qualitative Research). United States of America. Pearson Education.

Grabe, W. 2010. Reading in Second Language Moving from Theory to Practice. New York: Cambridge University Press.

Grellet, F. 1981. Developing Reading Skills A practical Guide to Reading Comprehension Exercise. New York: Cambridge University Press.

Harmer, J. 2007. The Practice of English Language Teaching (4 ${ }^{\text {th }}$ edition). England: Pearson Education.

Mikulecky, B. S. 2011. A Short Course in Teaching Reading Practical Techniques for Building Reading Power ( $2^{\text {nd }}$ edition). New York: Pearson Education.

Mistar, J. 2010. Pedoman Penulisan Thesis. Malang: Program Pasca Sarjana Universitas Islam Malang 
JARES, Vol. 3 No. 2 September, 2018; p-ISSN: 2502-826X; e-ISSN: 2503-1163

Copyrights@Balitar Islamic University, Blitar, Indonesia;

$\mathrm{Http}$ //jares.unisbablitar.ejournal.web.id

Slavin, R. E. 1995. Cooperative Learning Theory, Research, and Practice. Boston: A Symon \& Schuster Company

Utami, R. T. 2013. The Effectiveness of Using Computer Assisted Language Learning (CALL) on students' Reading Comprehension of MAN 1 Tulungagung. Malang. Islamic University of Malang 